\title{
Surplus and Exploitation
}

\author{
Phillip Anthony O'Hara \\ Curtin Business School, Curtin University, Perth, Australia
}

For: John Davis and Wilfred Dolfsma (Eds),

The Elgar Handbook of Socio-Economics

[V6a] [3 September 2006] [6pm] [5,956 words]

philohara1@yahoo.com

\section{Introduction}

Exploitation has a number of meanings in social economics, ranging from "reasonably utilising a resource for advantage", "unfairly utilising a resource for advantage", and "illegally utilising a resource for advantage". The type of exploitation examined in this article could be described in any of these ways, depending on the perspective of the social scientist. Indeed, various authors utilise "exploitation" in one or many of these three ways, variously emphasizing the more positive and others the more normative elements of the social process. Many authors, however, examine exploitation without the concept of surplus (e.g., Wertheimer 1996), and these works are not part of this essay. Specifically, this work links exploitation with surplus, in particular surplus product or surplus value.

A surplus in social economics is that portion of a product or financial arrangement left over after costs. Typically, for businesses it represents revenue minus costs of wages, materials and depreciation. Every society has a surplus, in the sense that, from time to time, the total production exceeds the necessary consumption of the people. However, the surpluses of some societies are larger than others. For instance, the surplus of hunter-gatherer societies may be only seasonal or cyclical, since such people prefer leisure and/or they fail to have the productive capacity to produce a surplus. In any case, there is not usually a large parasitic class to support from the surplus. Surplusses become more necessary in class societies, such as slavery, feudalism and capitalism. The historical rationale for capitalism is the production of a large surplus through technological change and industrial reorganisation. According to many social scientists it produces a surplus through the exploitation process. And so it is to capitalism that this essay commences the analysis of surplus and exploitation.

There are four main interpretations of surplus and exploitation from a social perspective. The first is the Pigou-Robinson neoclassical view where labor does not receive its marginal product. The second is the traditional Marxian view, 
based on a monetary labor theory of value. The third is a social economics view, where trust and sociality are an important part of the explanation. And the fourth is a social structure of accumulation view, based on institutions and history. These four interpretations are examined in this paper in successive sections, below. Afterwards we examine the nature of relatively egalitarians systems and whether they depend upon exploitation or not. A conclusion follows.

\section{Neoclassical Exploitation of Labor}

Exploitation of labor is not a theme that is very common in neoclassical economics, since workers are usually assumed to be paid their marginal productivity. For instance, if workers are paid a wage equal to the marginal product of their labor then it is usually concluded that there are being paid an adequate remuneration according to their level of productivity. But there are a few traditions, and even empirical evidence, to support some degree of exploitation and greater surplus when conditions are not consistent with workers being paid their marginal product. Usually this tradition follows that of the Professor Pigou and Joan Robinson literature. ${ }^{1}$

Joan Robinson (1933), for instance discussed a number of situations in which workers not being paid according to their marginal productivity leads to exploitation and higher surplus (super profit) for corporations. The first case is where there is a monopoly firm or a number of firms enjoying partial monopoly profit. Taking the case of a number of firms having a degree of monopoly power, the marginal net productivity of these firms will be lower than the marginal physical product of labor when valued at commodity price (1933: ch 25). The exploitation is thus due to a lack of competition in the industry, leading to above-normal profit and wages not commensurate with workers' marginal productivity. If competitive conditions were instituted output would rise, and the price of the commodity would decline to the even lower level of workers' marginal product. No worker exploitation would now occur, although workers wages themselves would likely have declined, along with the rate of profit. Thus, in this analysis, eliminating exploitation does not likely lead to improved workers conditions of pay.

The second case of neoclassical labor exploitation and higher surplus is where firms have effective monopsony power over labor. Joan Robinson provides some examples, such as the existence of a "gentleman's agreement" among firms not to bid up wages in response to a relative insufficiency of supply, which effectively gives these firms a form of monopsony power. Here the wage equals the supply price of labor but is less than the marginal physical product of labor. Hence exploitation exists because workers are not given a fair remuneration, leading to a higher rate of surplus or super-profit.

The other example is where there are cultural or social reasons for workers to reside in an area, despite a low wage, when workers could just as easily move to 
higher wage areas. They prefer not to due to locational advantages in the form of family and friends, environmental factors or upbringing. They may also not move to higher wage areas because of lack of information or ignorance (Robinson 1933:297). This leads to a relative oversupply of labor, or relative inelasticity of labor supply to other areas. In this case, wages are lower than workers' marginal physical product times price. Minimum wages will eliminate such exploitation, but may also lead to lower surplus, output and employment.

Some empirical evidence has been garnished by scholars as to whether such neoclassical exploitation exists in reality. Richard Vedder and Lowell Gallaway (1985), for instance, illustrate that such exploitation does not seem to have existed in the US between 1820 and 1920. Milan Zafirovski (2002), on the other hand, studied comparative data for the late 1990s and found varying rates of neoclassical exploitation ranging from high (UK, Australia, Canada) to medium (Japan, Netherlands, US) to low (Norway, Switzerland, Finland). The consolidation of neoliberalism is said to have raised the rate of exploitation as workers are not being remunerated in accordance with productivity due to greater power being given to corporations vis-à-vis labor.

\section{Traditional Marxian View of Surplus and Exploitation}

While the neoclassical vision of exploitation only operates when conditions of perfect competition do not prevail, Marxists start their analysis of exploitation under competitive assumptions. This view of surplus and exploitation starts off by explaining that under an advanced capitalist system there is a monetary expression of surplus and exploitation. In other words, the generation of the surplus through the process of exploitation mediates the spheres of production, circulation and distribution through the various social classes. The institutional conditions of existence of a surplus and exploitation are the first things to ascertain. These include:

1. Perfect competition exists in product markets, labor markets and money markets. It may be assumed to begin with that prices equal values, wages equal the value of labor power, and all surplus is distributed to capitalists.

2. There is control of the means of production in the hands of an elite social class of various industrial capitalists, who include the managers of enterprises in the commanding heights of industry. The means of production have been handed down through an array of processes linked to inheritance and conquest. Inheritance and conquest have enabled the regeneration of families who have established cultural, educational and business networks that reproduce differential control over the means of production, distribution and exchange. These means of production are socially controlled by this class of privileged people, who own the factories, machinery, buildings, computers, raw materials and other inputs into production. This leaves the majoring of the population who live off the fruits of their labor power; i.e., their ability to create value and hence 
to contribute directly to material and market relationships. This majority forms various classes of producers, depending on the historical phase of capitalist development, such as the workers at the point of production of mining, manufacturing, transportation, infrastructure, agriculture and services. In the contemporary form of capitalism this may take the form of the lower and middle ranks of the segmented labor market.

3. There are also various institutional conditions of existence of exploitation and surplus generation. For instance, it is necessary to employ various nonproductive agents to promote circulation and other functions necessary for exploitation. These include accountants, marketing divisions, sales workers, education, health, police and defence. These institutional supports provide unproductive labor that may indeed be critical to the reproduction of surplus value more generally conceived. Such unproductive labor enable the long-term generation of the conditions of existence of surplus value.

The production of surplus value requires various markets, such as the labor market, commodity market, financial system and global systems of supply and demand that propel the circuit of social capital, upon which surplus value depends. This is shown below:

Figure 1. The Circuit of Social Capital

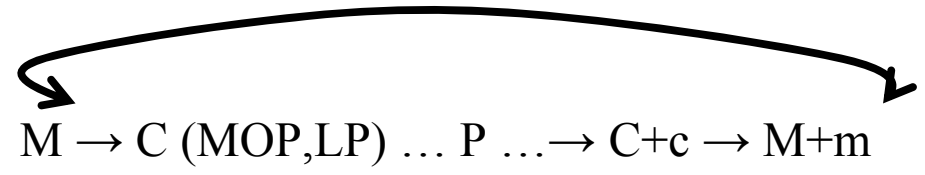

Here the supply of money (M) (from financial institutions and retained earnings?) are used to purchase commodity (C) inputs into the production process, including means of production (MOP) and labor power (LP). This is followed by the production process (...P...) where value-added is potentially generated. If the value-add is zero then total value is ' $\mathrm{C}$ ', but is surplus product is generated this is shown as ' $c$ '. However, before the surplus product can become surplus value, it must satisfy the Keynes problem, that if being sold in the commodity market for money. If the total money revenue is equal to ' $M$ ' then only the costs of production are met; but if a surplus value is generated then ' $\mathrm{m}$ ' is positive and exploitation has been successful. Afterwards, it is still necessary to reproduce the circuit of social capital further, as more money is reinvested into the circuit (as shown by the arrows).

The monetary theory of exploitation states that surplus value is generated in a monetary form and that the total product produced comprises constant capital $(\mathrm{K})$, variable capital (V) and surplus value (SV) in the three departments of means of production (department 1), consumer goods production (department 2) and luxury good production (department 3 ): 
$\mathrm{k} 1+\mathrm{v} 1+\mathrm{sv} 1$

$\mathrm{k} 2+\mathrm{v} 2+\mathrm{sv} 2$

$\mathrm{k} 3+\mathrm{v} 3+\mathrm{sv} 3$

$\mathrm{K}+\mathrm{V}+\mathrm{SV}=\sum \mathrm{GDP}$

Accordingly, the social rate of exploitation (rate of surplus value) is defined as $\mathrm{sv} / \mathrm{v}$, the organic composition of capital is $\mathrm{k} /(\mathrm{c}+\mathrm{v})$, and the rate of profit $\mathrm{s} /(\mathrm{c}+\mathrm{v})$, with the corresponding macro formulas also applying.

Surplus value is thus the process whereby labor power is exploited socially by capital in the pursuit of profit. More specifically, labor power is exchanged for wages, and surplus value is distributed between industrial capitalists (as profit), interest and charges (financial institutions), and rent (for rentiers). Exploitation occurs as capitalists are able to pay workers wages, but then extend their workday beyond this to produce a surplus product which is then sold on the market at a price which generates a surplus.

It is critical to the exploitation process that there be an array of markets, especially two: one, for separating the payment of wages (variable capital) and the other for selling the final commodity on the market (total price or value). If total revenue exceeds the wage and capital inputs then a surplus is produced, which then is expressed as profit, but may also be shared as interest and rent. A critical part of the story is that total labor equals total value of price produced and then realised on the market - workers create this value - but they are only paid their wages, which falls short of total revenue. Thus, exploitation occurs because the dominant class of owners and controllers of capital have a monopoly hold on the means of production, whereas workers have little or none and thus must sell their labor power for wages. This monopoly power thus enables capitalists to exploit workers, who receive wages according to the more competitive conditions of labor. If the ownership of the means of production, distribution and exchange were equally endowed by the whole population, and they were included in decision-making then exploitation of this type coluld not exist.

Exploitation is thus the most pervasive element in the generation of surplus value. It is justified through market ideology and entrepreneurial assumptions of creativity. The spontaneous role of the individual under capitalism is the dominant enabling myth underlying this process. The state also supports the process through various legal apparatuses that protect private property, plus police, armies and intelligence forces. The schools and universities also play their role in legitimising exploitation. When markets are assumed to be the dominant relationships of the economy it is easy to mystify the generation of surplus value, and failing to understand the nature of the veil over which we are taught that workers receive the value of their productivity. 
Surplus value is then distributed throughout the economy on the basis of various laws of competition and innovation. Through competition, for instance, the surplus value produced by the least efficient firm with the greatest amount of labor employed is redistributed to the most efficient with the smallest labor employed. Thus innovation does not generate surplus value per se but enables surplus value to be distributed from workers in inefficient sector to those in more efficient ones. Competition may also encourage firms to quickly put into practice the latest innovations, thus leading to higher organic compositions of capital $(\mathrm{k} /(\mathrm{k}+\mathrm{v})$, and lowering the rate of profit. This occurs through an increase in depreciation of capital as firms are forced through competition to introduce the latest forms of technology even if in the long run their profit rate will decline.

Many authors have related these processes of exploitation and the production of surplus value to national income accounts. For instance, O'Hara (2006) has done this for China, and the results are shown below:

Table 1: Rate of Economic Surplus, Exploitation, Organic Composition of Capital and Profit: China 1978-2002 ${ }^{2}$

\begin{tabular}{|l|l|l|l|l|l|}
\hline & 1978 & 1984 & 1990 & 1996 & 2002 \\
\hline Economic Surplus/GDP & 0.32 & 0.28 & 0.25 & 0.24 & 0.24 \\
\hline $\begin{array}{l}\text { Rate of Exploitation } \\
(\mathrm{s} / \mathrm{v})\end{array}$ & $56 \%$ & $46 \%$ & $40 \%$ & $39 \%$ & $41 \%$ \\
\hline $\begin{array}{l}\text { Organic Composition of } \\
\text { Capital (c/(c+v) }\end{array}$ & 0.16 & 0.16 & 0.18 & 0.20 & 0.24 \\
\hline Rate of Profit (s/(c+v)) & $47 \%$ & $40 \%$ & $33 \%$ & $32 \%$ & $32 \%$ \\
\hline
\end{tabular}

Source: Adapted from O'Hara (2006)

Studying the trends and nature of these variables reveals a quite obvious process of development. The Chinese authorities have set in motion a style of social capitalism, where it has encouraged competition, globalization and the expansion of capital accumulation. It has utilised the capitalist mode of production and reproduction to stimulate industrialisation, in the context of a high degree of competition of Chinese products on the world market. Expanding capital accumulation and thus raising the share of investment in GDP to over $40 \%$ raises labor productivity to successively high levels.

This has the ramifications of reducing the rate of profit from the previously very high rate of $47 \%$ to the still high (in global terms) but moderate by Chinese standards of around 32\%. John Knight and Shi Li (2005) point out that during the period of central planning the state owned enterprises were "highly profitable" since they employed a price-scissors policy of "keeping industrial prices high and agricultural prices low in order to finance industrialization" (p. 206). But during the period of reform from 1978 onwards, greater competition reduced margins and cut profit rates in both state and many private firms. The profit rate was reduced through the incessant expansion of capitalist production, especially the continual investment and replacement of labor by capital in the 
ongoing process of global competition. Substituting labor for capital raises labor productivity, but it also reduces the productivity of capital as the rate of investment rises faster than GDP. The higher capital/labor ratio translates into a higher organic composition of capital, which thus reduces the rate of profit. Chinese enterprises are, in this sense, poorly managing their capital investments and relying more on accumulation and substitution of labor rather than capital improvements per se.

China is thus exploiting workers at a lower rate than previously, but nevertheless the exploitation process forms the foundation of profit, accumulation and growth of the Chinese system of capitalism.

\section{Social and Cultural View of Exploitation and Surplus}

The traditional Marxian view of surplus and exploitation can be extended somewhat to provide a more social and cultural perspective on the matter. Much of this vision emanates from Thorstein Veblen and other social economics. Veblen, for instance, believed that the net product (surplus product) is created not just from workers being exploited, but also from the use of social knowledge and institutions. In other words, system functions of knowledge, trust and circulation create some of the surplus product, and demand also may contribute to it by transforming surplus product into surplus value or profit. Institutions, in general, may thus contribute to the surplus by performing public goods functions that generate long-term profit.

This can be shown by extending the circuit in various ways, such as by the introduction of the world economy, the state, the corporation, and so on (see O'Hara 2001). ${ }^{3}$ We seek to extent the circuit through the introduction of family relations, trust and association, and cultural factors via a more complex "systemic circuit of social capital" (SCSC), as illustrated below in Figure 2:

Fig 2. Systemic Circuit of Social Capital

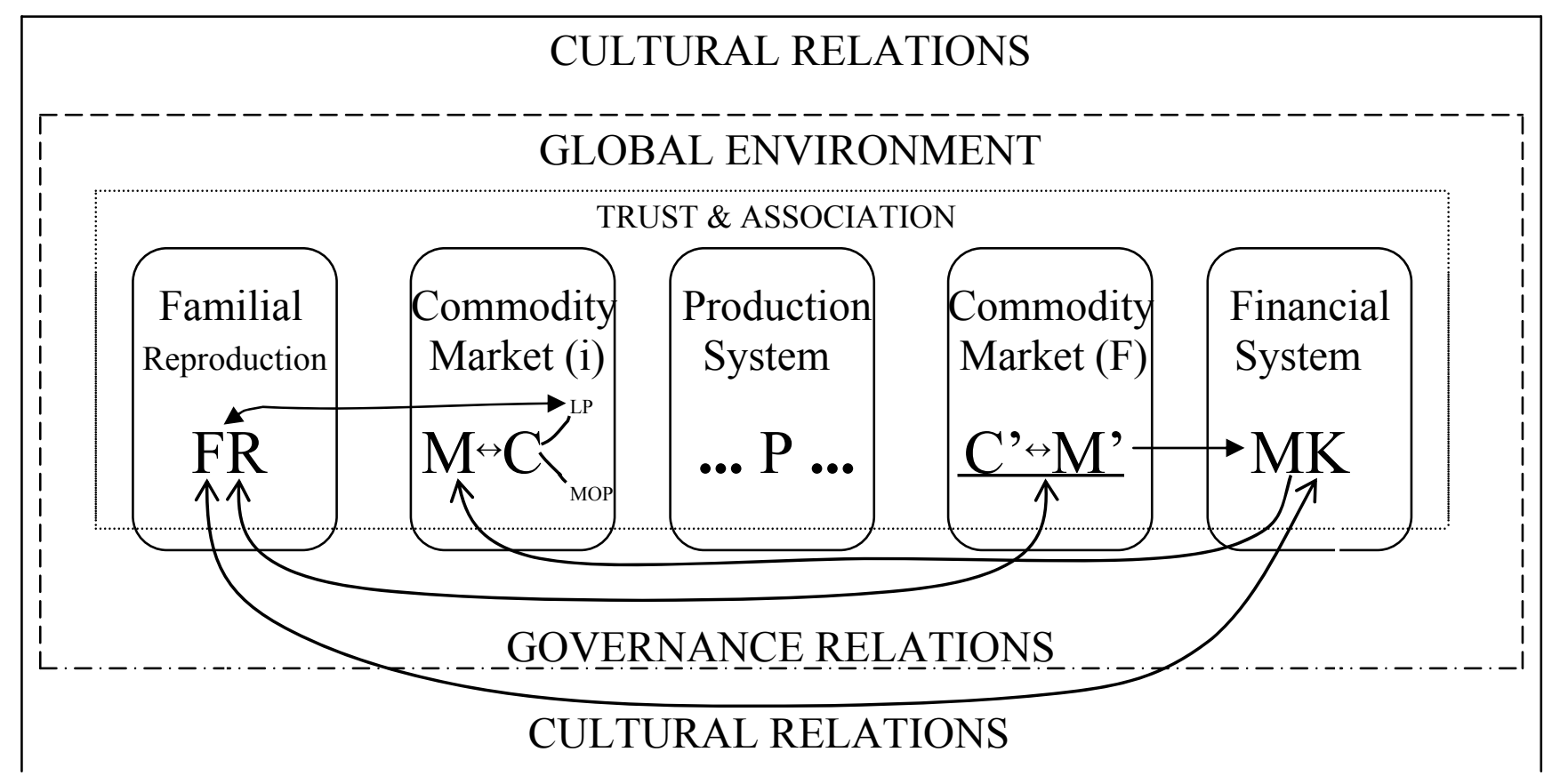


The SCSC illustrates, firstly, how the reproduction of social and material relations of production and circulation are embedded in a system of "cultural relations", which constitutes the way of life of the community, including the differential norms, mores and practices of the people. Culture also includes the relations of status, ceremony as well as class, ethnicity and gender, which have regional variations and modes of uneven development. Secondly, the reproduction of the SCSC is embedded in a "global environment" as well as "governance relations" that embody the rules, laws and regulations channeling and directing the practices of individuals, corporations and groups. Thirdly, the SCSC is embedded in a myriad of relations of "trust and association" through global, regional, national, corporate, social, familial and individual processes.

Set within this broad institutional and social environment, the SCSC, more narrowly conceived, can be seen to "commence" with a system of "familial reproduction" (FR), which constitutes the roles, practices and forms of care that are embedded in households; between parents, children and others. Familial reproduction potentially enables the emergence of a stable environment for people to structure their social practices, and for personality and emotions to evolve. Closely linked to the family are relations, friends and community linkages. The trust and association developed in the family may help the market for intermediate goods and service (i) through enhancing the quality of labor power and conditioning consumption patterns and spending decisions.

The second dynamic structure of the inner SCSC includes decisions to exchange money for labor power and means of production in the market for intermediate goods and services. This involves agreements and relationships between capital and labor (or their representatives) in the distributive struggle over shares of national or international income. It also involves structures of competition and pricing in the market for capital goods and material inputs; including machinery, factories, oil, gas and other raw materials. Bottlenecks at this phase of the circuit can have a major negative impact on the reproduction process as a whole. Family relations, trust, association and culture can also impact on these practices.

The third phase of the inner SCSC involves the direct production process, including the valorization of capital, which includes the production of surplus product. This involves all the major relations and processes associated with the ability of capital to subordinate labor and extract surplus labor through an array of technological, organizational, supervisory and governance structures. However, before the surplus product can become effective, it requires a fourth phase, that of the realization process through "final" market demand (F). Without the ability of capitalism to create sufficient demand - through a combination of consumption, investment, government spending and/or net exports - the surplus value remains only potential rather than actual. Familial 
relations and trust are important to this process. And lastly, for the CSC to be fully reproducible requires that corporate finance (M'), or endogenous money and credit through the financial system (MK), be (re)invested into the market for intermediate goods and services as well as through the system of familial reproduction. And so on ad infinitum as the circuit becomes reproduced through varying turnovers of capital.

This social way of viewing exploitation and surplus value recognizes that profit, interest and rent becomes a form of monopoly ownership income that is generated by exploited the system conditions of trust, institutions, knowledge, and the environment. Business thus is able to exploit the social value by controlling, again, the means of production, distribution and exchange. Indirectly, this may be a form of worker exploitation because the workers are not sufficiently included as owners of capital and therefore are denied a share of the surplus. Underdeveloped nations similarly are exploited in this becuae they do not share in the global surplus created in part by the public goods of financial, civil, material and social relations generated in society.

\section{Social Structure of Accumulation Exploitation and Surplus}

A subset of the social explanation of exploitation and surplus is provided by the social structure of accumulation school of political economy. It argues that institutions specifically provide the foundation for most of the long-term growth and development occurring in society. Therefore, certain classes of people are able to exploit these institutions for their own benefit, and thereby gain a material and social advance on other classes.

For instance, most nation states utilize the institutional spheres provided by the family-community, the production-distribution system, state and governance, and the system of trade and finance for reproducing surplus value. This is shown below:

Figure 1.1 SSA Systems Production and Distribution

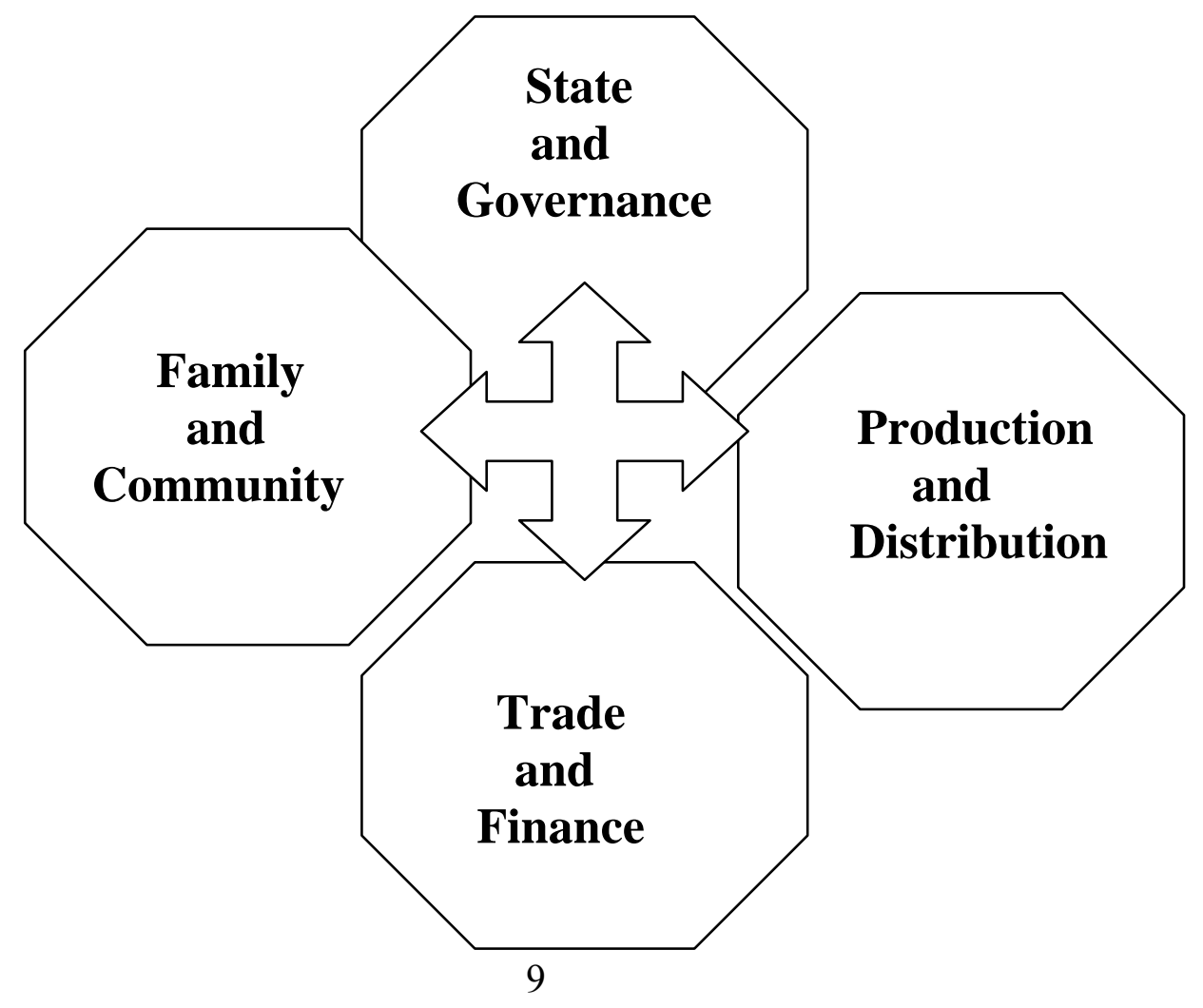


The SSA approach to surplus and exploitation has two layers. The first layer says that exploitation in the short-term is undertaken of workers by capitalists and their functionaries, resulting in the production of a surplus. The second layer says that the long-term conditions underlying exploitation is institutionalised through an array of social arrangements.

The family and community play a role in the reproduction of labor power, sociality and trust, upon which the rest of the institutions depend. The work of females is of special relevance here since it is them who perform most of the household labor of child rearing, non-market production and domestic psychological counselling. Without the coordinating power of women the reproduction of potential workers and capitalists would be severely hindered. Hence they produce what may be called an "underlying institutional surplus" of social cooperation and connectedness that are necessary for long-term socioeconomic reproduction. Periodically the family and community become dislocated as individualism, work and rapid social change upset established human relationships, and this can inhibit long-term growth, surplus and exploitation.

The state plays a critical role when directed to productive capital, such as education, infrastructure, communications, health and utilities. Historically, the state has provided a critical element of public goods type goods and services that stimulate economies of agglomeration, human capital and the circulation of socioeconomic activities. The state in more recent historical examples has also specialised in providing counter-cyclical automatic and discretionary spending as well as prudential functions along with lender of last resort facilities. The public goods functions underlying these activities have historically been critical for the production of a social surplus, as well as to promote stability in the conditions underlying exploitation in corporate relationships. However, when unproductive activities dominate resulting in crowding out of private investment this usually sees increasing reliance on handouts such as subsides, benefits and general consumption that inhibit surplus generation and exploitation.

The corporate system itself has been critical for the provision of systems of management, organisation and technological change underlying long-term accumulation. It has also structured the labor process through an array of supervisors, overseers and labor relations personal whose task it is to extract labor from labor power more effectively. More specialisation in the firm create divisions such as marketing, sales and $R \& D$ divisions that concentrate on various aspects of the reproduction of goods and services provision. The corporation also functions as a form of protection from the market to promote a degree of oligopoly extraction of surplus distributed from the less to the more productive firms. However, the contradictions can often dominate as systems of technological maturity settle in, conflict between capital and labor is pronounced, and institutional sclerosis dominate. 
Trade and finance also critical to long-term growth and accumulation underlying the rate of surplus value or exploitation. The transformation of use values through transport itself creates surplus value and ensures the greater circulation of capital. Circulation routes through shipping, air, and road transport enhance the spatial reproduction of capital. It also promotes a greater degree of market penetration of countries and continents until now not open much to capitalist production. It thus promotes the rate of exploitation and the turnover of capital, providing a double boost to profit.

And the finance system potentially stimulates the rate of turnover of surplus value, as well as ensuring the continuation of exploitation through production in the workplace. In this way it functions to enhance long-term reproduction. But it can also, as with most contradictions, inhibit long-term growth through an excessive expansion of fictitious capitals, such as speculative bubbles associated with share markets, property markets and high-tech markets. When finance thus dominates industry this increases the degree of instability in the macro economy and thus inhibits surplus production and exploitation.

Overall, this social view of surplus and exploitation processes recognises that public goods functions can operate within institutions, and these social relationships are in essence the foundation of long-term profit and growth (O'Hara 2006a). In this sense, individuals and groups of people are able to extract the surplus in the long run through exploiting the very institutions that propel progress and development. Hence, exploitation is not simply one of one class versus another, but also of groups of people controlling the institutions themselves, including the media, political processes and the commanding heights of innovation.

\section{Exploitation and Surplus in Egalitarian Societies}

The question now arises as to what might be the nature of exploitation and surplus in more egalitarian societies. Can socialism, for instance, exist without exploitation? If so, does it still produce a surplus? These are the critical questions that have led to many theories and solutions to the problems of moving from class to non-class societies. Four types of egalitarian societies are examined here: profit-sharing systems of capitalism; state-based societies; worker cooperative-based societies; trust-and-sociality structures.

The first type of more egalitarian system is the profit-sharing corporate system of democratic capitalism. Here, workers receive a share of the profits, according to the rate of profit and their position in the firm. For instance, a corporate system could be based on a method of distributing surplus to workers when the rate of profit is above 10 percent. In this case, thirty percent of the extra profit may be distributed to workers as bonuses, depending on the nature and position of the respective workers. In this case, both exploitation and surplus exist since the rate of exploitation may have simply declined from $33 \%$ to $25 \%$; or the profit sharing arrangement may be a form of efficiency wages where productivity expands, along with total wages, such that the rate of exploitation does not change. 
The second type of egalitarian system is where the state controls much of the surplus, either through greater corporate taxes or through controlling the dominant enterprises. In the case of the state owning and controlling dominant industries, it represents the collective capitalist. It therefore uses the institutions of business to extract surplus value and hence to exploit workers. However, the rate of exploitation also depends on what is done with the surplus. If the state utilises it for further innovation, employment, education, health and infrastructure, as well as cultural venues and public transport, then some of the surplus may be redistributed to workers, thus lessening the rate of exploitation. But if the public utilities are financed purely in order to promote public investment then the corporate system's exploitation of labor continues unabated.

The third type of egalitarian system is where there is an expansion of worker cooperatives as a systemic response to social needs of workers and production. This may result in a system like the Mondragon Group of Companies, in the Basque area of Spain. Here, productivity is high since workers are included in decision-making, electing members of the board, which appoints managers; and supervisors are generally not needed since social factors enhance the commitment of workers to the collective concerns of production, distribution and exchange. A portion of the surplus is distributed to company tertiary institutions, medical assistance, banks and housing cooperatives. Here the workers are not exploited since they control the company processes, but the surplus is democratically distributed into productive and social institutions. Exploitation thus does not exist, even with a surplus, when the workers themselves make such decisions.

\section{Conclusion}

This essay has examined three social perspectives on exploitation and the surplus. The first one is the neoclassically-conceived view of exploitation and super-profits based on labor not being remunerated according to their marginal productivity. However, generally exploitation is due to monopoly or monopsony conditions and inelastic labor supply curves, where raising the wage does not usually reduce such exploitation. The second view of exploitation is the traditional Marxian theory which emphasizes the collective exploitation of workers forming the basis of capitalist development. Here, increasing wages usually does reduce exploitation. The third and forth forms of exploitation are modifications and extensions to the traditional Marxian explanation. Thus the third and fourth types are both more socially-oriented forms of exploitation; the third linking to cultural arrangements that impinge on trust and sociality; and the forth forming part of the long-term reproduction of the conditions of existence of exploitation and surplus production in the social structure of accumulation approach. In both highly social perspectives it is possible for the dominant social classes to exploit the institutions for their own ends. Here the long-term surplus is reproduced through an array of institutional conditions and accords, as a public good. 
Then we examined four types of relatively egalitarian societies. The first has a profit sharing facility, where exploitation still exists but there is a stimulus for workers to create a larger surplus. The second system is where the state produces and distributes the surplus. Under this system the rate of exploitation tends to be high if the state reinvests the surplus into production, distribution and exchange systems. But if the state recreates community through propelling cultural services, health, education and means of community involvement it may reduce the rate of exploitation and even enhance social and economic democracy. The third system, though, is the only one where exploitation ceases, since workers control the firm, decide what to produce, and recreate community capital and production systems simultaneously.

\section{References}

Arthur, Christopher J and Geert Rueton. (1998) (Eds) The Circulation of Capital: Essays on Volume Two of Marx's 'Capital'. London: Macmillan.

Baran, Paul A. (1957) The Political Economy of Growth. New York: Monthly Review Press.

Boss, Helen. (1990) Theories of Surplus and Transfer: Parasites and Producers in Economic Thought. Boston \& London: Unwin Hyman.

Braverman, Harry. (1974) Labor and Monopoly Capital: The Degradation of Work in the Twentieth Century. New York \& London: Monthly Review Press.

Chamberlin, Edward Hastings. (1933) The Theory of Monopolistic Competition: A Re-orientation of the Theory of Value. Cambridge, Mass: Harvard University Press, 1962.

Danielson, Anders. (1994) The Economic Surplus: Theory, Measurement, Applications. London \& Westport, CT: Praeger.

Davis, John. (1992) The Economic Surplus in Advanced Economies. Aldershot, UK \& Brookfield, US: Edward Elgar.

Paul Flatau (2001) "Some Reflections on the 'Pigou-Robinson' Theory of Exploitation", History of Economics Review, Number 33, pp. 1-16.

Foster, John Bellamy. (1986) The Theory of Monopoly Capitalism: An Elaboration of Marxian Political Economy. New York: Monthly Review Press.

Hahnel, Robin. (2006) "Exploitation: A Modern Approach", Review of Radical Political Economics, Volume 38, Number 2, Spring, pp. 175-192.

Marx, Karl. (1867) Capital, Volume 1 - The Process of Production of Capital. Harmondsworth: Penguin, 1976.

Marx, Karl. (1885) Capital, Volume 2 - The Process of Circulation of Capital. Harmondsworth: Penguin, 1978.

Marx, Karl. (1894) Capital, Volume 3 - The Process of Capitalist Production as a Whole. Harmondsworth: Penguin, 1981.

O’Hara, Phillip Anthony. (2004a) "A New Family-Community Social Structure of Accumulation for Long Wave Upswing in the United States?", Forum for Social Economics, Volume 34, Number 2, Spring, pp. 51-80. 
O’Hara, Phillip Anthony. (2006) “A Chinese Social Structure of Accumulation for Capitalist Long-Wave Upswing?", Review of Radical Political Economics, Volume 38, Number 3, Summer, pp. 397-404.

O'Hara Phillip Anthony. (2006a) Growth and Development in the Global Political Economy: Social Structures of Accumulation and Modes of Regulation. London and New York: Routledge.

Perri, Stefano. (2003) "The Counterfactual Method of Marx's Theory of Surplus", Review of Political Economy, Volume 15, Number 1, pp. 107-124.

Robinson, Joan. (1933) The Economics of Imperfect Competition. Second Edition. London \& Basingstoke: Macmillan \& St. Martin's Press, 1969.

Roemer, John E. (1982) A General Theory of Exploitation and Class. Cambridge, MA: Harvard University Press.

Stanfield, James Ronald. (1973) The Economic Surplus and Neo-Marxism. Lexington, MA: Lexington Books.

Vedder, Richard K. and Lowell E. Gallaway, (1985) Productivity and Wages in the American Economy: A Tale of Two Centuries. Working Paper. Ohio University, Department of Economics.

Weeks, John. (1981) Capital and Exploitation. London: Edward Arnold.

Wertheimer, Alan. (1996) Exploitation. Princeton, NJ: Princeton University Press.

Zafirovski, Milan. (2003) "Measuring and Making Sense of Labor Exploitation in Contemporary Society", Review of Radical Political Economics, Volume 35, Number 4, Fall, pp. 462-484.

\section{Notes}

1. Paul Flatau (2002) argues, however, that while they have much in common, Piguo's and Robinson's theories of neoclassical exploitation are somewhat different from each other. Edward Chamberlin (1933) went further than Pigou and Robinson and argued that under conditions of monopolistic competition "all factors (not merely any one, say, labor) receive less than their marginal products“" (p. 182).

2. The data in Table 4, including the economic surplus, organic composition of capital, rate of exploitation and rate of profit are all estimated from the national accounts data. The "economic surplus", for instance, called "operating surplus" in the national accounts, is defined as "a residual" and it "reflects economy-wide business profit". It is "the return to the owners of the capital involved in a productive activity, and thus constitutes [in principle] the economy-wide return on equity". Furthermore, "surplus constitutes the return on" "fixed and intangible assets". The rate of exploitation is defined as the ratio of economic surplus/GDP divided by the ratio of labor share/GDP. (See Carsten Holz 2005.) The organic composition of capital is here specifically defined as the depreciation proportion of GDP divided by the depreciation and wages 
proportions of GDP. It does not include circulating capital but, nevertheless, is thought to be a good indicator of the trend direction of the organic composition of capital.

3. The project of modifying and extending the CSC is a critical one in contemporary political economy. This is because the CSC is a powerful tool of analysis, yet the contemporary economy is a complex one that requires expanding the linkages in the analysis. See previous chapters for further applications of the circuit of social capital to the global and national economies. 